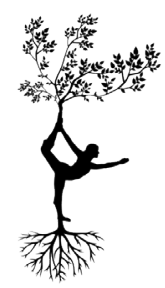

$21^{\text {sT }}$ CENTURY PEDAGOGY

Transformations of the Education Systems in Europe and in Asia

at the turn of $20^{\text {th }}$ and $21^{\text {st }}$ century

Vol. I, 16-19

DOI: $10.2478 /$ ped21-2018-0003

Salidin Kaldybaev

Ala-Too International University, Kyrgyz Republic

\title{
Reform Analysis in Higher Education System of the Kyrgyz Republic
}

Key words: Higher education, education reform, normative documents, public education development programs, the Education Act, the state educational standard, higher education institutions

\begin{abstract}
A b st ract
At the end of the twentieth century the Kyrgyz Republic got the opportunity to create a higher education system, as well as the way was paved for the creation of a common educational space in the Commonwealth of Independent States (CIS), which resulted in adopting CIS-wide a number of documents that form the legal basis for a common educational space. Analysis of reforms in education system of Kyrgyzstan allows concluding that in general, the state educational policy of sovereign Kyrgyzstan was entirely aimed at solving strategic problems of the education sector, and thus at improving the socio-economic well-being of the country. Lack of continuity and the proper funding of the adopted state programs have negative impact on the effectiveness of educational reform. Therefore, a number of measures ought to be taken in order to improve the efficiency of the education system reform.
\end{abstract}

In the age of globalization the special role belongs to the higher education system, which is becoming one of the leading production sectors, providing an increment of human capital. Higher education reform is becoming a strategic priority for any state. It naturally leads to a change in the value of paradigm, which focuses not only on the current but also future needs of society. Gaining independence of Central Asian countries also started the development of their own educational models. The peculiarity of the higher education models were explained by the differences in the social discoveries and the differences on the issue of transition to a market economy of the country. According to experts, the preservation of the elements of the old command economy is forcing reforms in education.

At the end of the twentieth century the Kyrgyz Republic got the opportunity to create a higher education system, taking into account the achievements of the world's educational systems. At the same time, the tradition and the experience of cohabitation in the Union paved the way for the creation of a common educational space in the Commonwealth of Independent States (CIS). In the late 90-s in the CIS-wide a number of documents that form the legal basis for a common educational space has been adopted:

- Concept of formation of common (general) edu- 
cational space of the Commonwealth of Independent States;

- Agreement on cooperation to form a common (general) educational space of the Commonwealth of Independent States;

- Regulations on the Board for Educational Co-operation of member-states of the Commonwealth of Independent States.

In accordance with these documents and taking into account the rules of international law of the CIS countries, including Kyrgyzstan pledged to strive for convergence of education systems, including organizational structures, contents, forms and methods of education, admission requirements and requirements for graduates.

Thus, the conditions for young people have been created to have access to higher education, with the right to choose universities and recruitment right in the Commonwealth country. As part of a common educational space it has been provided mobility of students, postgraduates, teachers and researchers, recognition of documents of education, academic degrees and titles. The adopted documents noted that the common concern should be improvement of the quality of education at all levels and in all types of educational institutions, especially in high school. It provides strengthening scientific training, using innovative technologies and teaching methods, increasing the training of teachers, etc.

But in spite of the common intention of the union in matters of structure and development of the higher education system, every state in Central Asia tried to solve the accumulated problems in their own way.

Since independence in Kyrgyzstan, expenditure on education has significantly reduced. The report of the UNDP Human Development Regional Office noted that in Kyrgyzstan in the period between 1990-2001 the quota of education expenditure in GDP has reduced by 8.3 to $3.1 \%$ (while the worldwide average is 4,1\%) (www.24.kg/news-stall/print:page,1,72221).

But, despite this, the Kyrgyz Republic participated in all intergovernmental agreements and programs of cooperation concluded within the framework of the CIS, in almost all aspects of education. Today, despite the complexity of everyday life, Kyrgyzstan has ideas to improve the content and the quality of life with education.

Kyrgyzstan in recent decades has experienced significant changes in the field of higher education that have affected the philosophy of education, its global goals and objectives, organizational structure, content of education, approaches to the development of educa- tional standards and curriculum, forms and methods of education quality assurance, monitoring of educational institution activities, financing and many other aspects.

At the initial stage of democratic modernization of society, in 1991-2000 the Constitutional Provisions are identified, the Education Act is adopted, the National Doctrine and the State Concept of High School Development, the National "Bilim" Education Program is formulated, the State educational standards are developed, licensing rules, conditions and requirements are set.

Declaration as "The Year of Education" of 1996 in the country and the related different national events aimed at the development of education was of great importance in the implementation of state educational policy.

Abdyrakhmanov T.A. in his dissertation work has divided the post-Soviet Kyrgyz Republic educational policy of 1991-2005 into two periods: "positive" (1991-1999) and "stagnation" (2000-2005), since "during this period the education system as part of the crisis society was exposed to crises phenomena, which led to a significant slowdown in the pace of development" (Abdyrakhmanov, 2010, p. 2).

The Kyrgyz Republic Education Act (1992, as amended in 1997) - the first in the history of the republic document that become the basis of the educational activities in a sovereign state. In 1996 it is adopted the state program "Bilim", providing for the improvement of the legislative framework, updating the content of education, quality growth, social protection measures of students and teachers, development of sustainable funding mechanisms for educational institutions.

The following documents have been developed and adopted: "Cadres of the XXI century" Presidential program (1995), "Araket" National Programme for Poverty Reduction (1998), "Ayalzat” National Program (1997), "New Generation" National Program (2001), the "Education for All" National action plan (2002), National poverty reduction strategy (2003) and others. These programs were aimed primarily at ensuring the accessibility and quality of education.

In May 2000, it was adopted the National Doctrine of Education in the Kyrgyz Republic until 2020, which was an important step in strengthening cooperation between the state and society in the development of the education sector.

In order to ensure equal access to higher education and eradicate corruption, national testing was introduced in 2002 (ORT) - funded by the US Agency for International Development (USAID) and the technical 
support of American Councils for International Education (ACCELS) (Kubaev, 2004, p. 57-96).

These strategic documents reflect the main trends of development of education system, the expected results and the ways to achieve them. In their development, a new approach based on deep analytical work and involvement of all interested parties to identify strategic priorities has been applied.

If in the institutional context, only 1 university and several institutions made a system of high school in the Soviet Kyrgyzstan, the post-Soviet system of higher schools of the republic is represented by academies, universities, institutes and conservatories. Among them a special status, the status of "National", is used by several institutions of higher education of the country, although this status is formal.

Thus, the higher vocational education in Kyrgyzstan is a network of 54 institutions of higher education, of which 32 are public and 22 private.

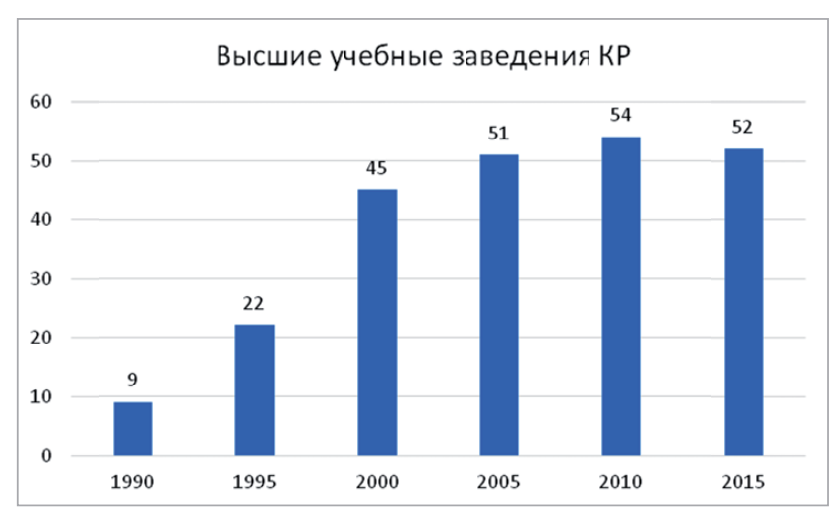

Figure 1. Growth in the number of universities in Kyrgyzstan since independence

More than 218 thousand students are studied in higher education institutions of the Kyrgyz Republic, as a result, if in 1990, 130 students was accounted for by 10 thousand of population of the republic, at the present time, the figure is 410 (Kutbilim, 2012).

Due to the openness and adaptability of higher vocational education system in Kyrgyzstan, it has sharply increased the number of foreign students in the country, many Kyrgyz citizens are studied in many universities abroad, including in universities of the CIS and SCO countries (www.24.kg/news-stall/print:page,1,72221).

Category of interstate higher educational institutions of the republic is made by such universities as the American University of Central Asia, Kyrgyz-Russian (Slavic) University in Kyrgyzstan, "Manas" Kyrgyz-Turkish University, Kyrgyz-Russian Academy of Education, Kyrgyz-Uzbek University, and others.
The structure of international universities includes Mahmood Kashgari-Barskani Kuwait University and Ataturk-Alatoo International University.

It should also be noted that if in 1991, the high school in Kyrgyzstan has fully been funded by the state budget and the training of students of the country has also been financed by the state, in 2013, students enrolled in the state budget financing amounted to only $12.1 \%$ of the total number of country's students. The average annual expenditure per student studying at the expense of state budget was approximately KGS5400 in a year, although the actual annual demand of funds for student training were two to three times more. As a result of this, from year to year the public funding of higher education system is remained insufficient. According to the calculations of some institutions of higher education, it covers only $15-20 \%$ of university expenditures required for the preparation of specialists. Therefore, the remaining part of universities expenditures is reimbursed by special means. This means that students studying extrabudgetary are co-financing training of the students studying at the expense of the state budget (Kutbilim, 2012).

Only Osh Humanitarian and Pedagogical Institute works at the expense of the municipal budget. Bishkek State University is formally considered another municipal university, but its status as a municipal institution has not yet been fully defined.

For the purpose of integration of higher vocational education in the international educational space, in 2011 the Government of the Kyrgyz Republic has adopted the Decree "On establishing bilevel structure of higher vocational education in the Kyrgyz Republic". When transferring to bilevel system it was important not to lose the valuable tradition of fundamental education, which has been accumulated over the years of existence of higher education. In 2012, it was adopted very important documents - the Development Concept of Education of the Kyrgyz Republic until 2020 and the Development Strategy of Education until 2020, which proclaimed the important guidelines, consolidating values and priorities for the Kyrgyz education system (Kutbilim, 2012). The documented pointed to the necessity of transition to education focused on the end result.

In order to optimize the structure and content of higher education the state educational standards of new generation have been developed based on the competence model. New generation standards are aimed at providing a common educational space in the country, a single level of education obtained by students in dif- 
ferent types of educational institutions, with different forms of organization of educational process.

The standardization of higher education based on competence approach is caused by the desire of Kyrgyzstan to enter the system of world culture, which requires consideration of the achievements of the international educational practice in the formation of education. First of all, this is due to the introduction of the principles of Bologna process in the system of education in Kyrgyzstan.

Analysis of reforms in education system of Kyrgyzstan allows concluding as follows:

First, in general, the state educational policy of sovereign Kyrgyzstan was entirely aimed at solving strategic problems of the education sector, and thus at improving the socio-economic well-being of the country. Lack of continuity and the proper funding of the adopted state programs have negative impact on the effectiveness of educational reform.

Second, in order to improve the efficiency of the education system reform it should be:

- monitored and assessed the efficiency of the newly adopted programs, concepts, etc.;

- granted autonomy, greater powers and freedoms to heads of educational institutions in the allocation of domestic resources;
- developed higher education management system;

- state needs to develop a clear mechanism to ensure qualified teaching staff of universities, increase the prestige of the teaching profession;

- actively attracted investments in the education sector.

\section{Bibliography}

Abdyrakhmanov T.A. (2010). Higher vocational education of the Kyrgyz Republic as a major factor in solving the social problems of a society in transition. Bishkek.

Kubaev B.H. (2004). Development concept of education of the Kyrgyz Republic until 2010/Collection of statutory instrument in education of the Kyrgyz Republic. Bishkek.

Kutbilim (2012). Development concept of education of the Kyrgyz Republic until 2020. Bishkek.

Kutbilim (2012). Development strategy of education of the Kyrgyz Republic for 2012-2020. Bishkek.

Report on Human Development in Central Asia. Moving forward without barriers: Regional cooperation for human development and buman security. Bratislava. (www.24.kg/news-stall/print:page,1,72221). 